\title{
THE DRIVER
}

\section{On the road to freedom.}

\section{BY RAHUL KANAKIA}

$\mathrm{E}$ very day for the past 30 years, Vlad had woken up to find the black Lincoln town car already idling in front of his house. Today was no different. As Vlad made his coffee, the car slowly rolled up and down the block. When he walked to the spot where he'd parked his own car, it rolled along at his side like a well-trained dog. On the freeway, it was three car-lengths behind him. In the university parking lot, it pulled into the space right in front of Vlad, and the professor stared directly into the eyes of the driver. Vlad waved at him. The driver nodded.

The driver was in his late forties, with a neatly trimmed salt-and-pepper beard and receding hairline. He was wearing a white polo shirt with an indistinct company logo over the right breast. Vlad didn't know how tall the driver was, because he had never seen the driver outside the car.

Over the years, Vlad had witnessed the driver ploughing through two pedestrians and ramming four cars off the road in three separate incidents. And once, when the child Vlad was on his bike, deciding which path to take, the window of the car opened up and the man said: "Left." When he got home, Vlad's worried mother told him of the gas explosion on the right-hand path that had killed three people.

By the time Vlad reached his ground-floor office, the car was parked in the quad, right next to the department's doors. It usually stayed there, within spitting distance of Vlad's window, until Vlad left. Bikes wove between it and the wall. Students stepped around it. Sometimes police officers came by and ticketed the car. Once, Vlad checked the citation number on several of these tickets. They were all paid promptly and electronically, within moments of the ticket being registered.

Vlad looked out of his window. It was a wonderful day. The birds were singing. The coeds were wearing sundresses. The sky was clear. The breeze was cool and vigorous. Vlad picked up the folding chair he kept in a corner of his office and decided to eat lunch with the driver.

It had taken years for Vlad to convince the driver to roll the window down at his approach. That had been such a triumph for the young Vlad. Now the driver smiled as Vlad walked up and unfolded his chair.

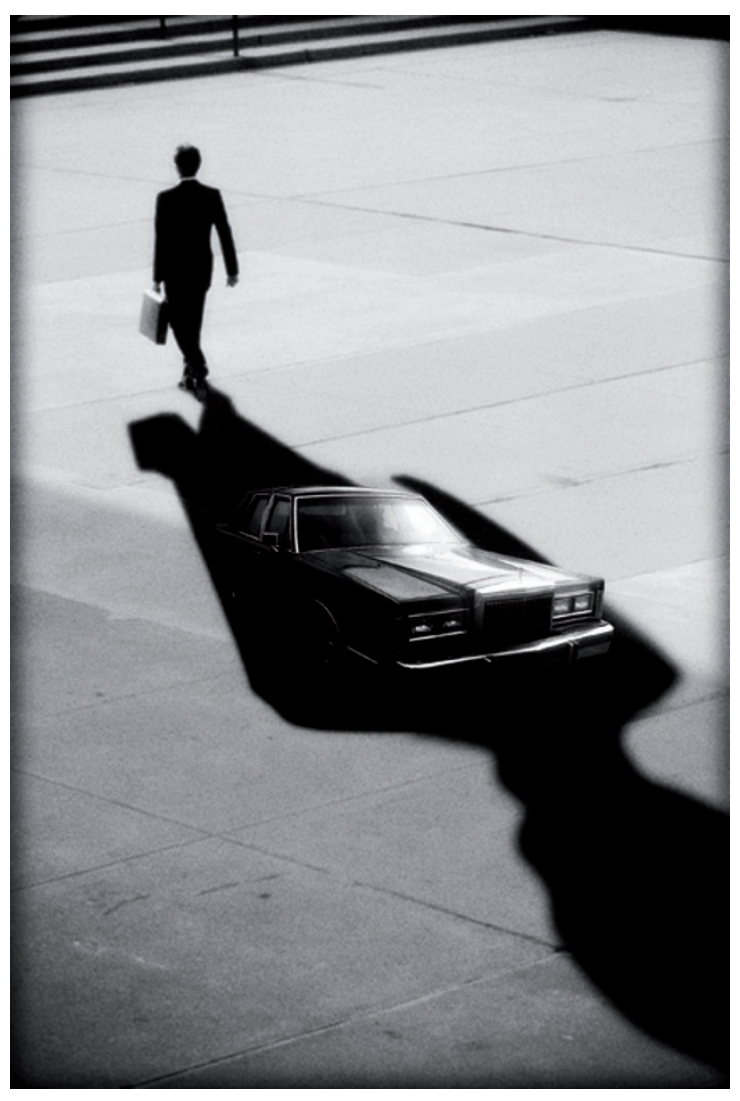

"How is your reading?" the driver said.

"Don't you know better than me?" Vlad said. He unwrapped the sandwich he'd purchased from the deli and handed half through the open window to the man.

"The directorate has stopped contacting me," the driver said.

"What about the other Vlads? Have they made the breakthrough yet?"

"I don't know. Even the other drivers won't speak to me."

"For how long now?"

"A few months," the driver said. "I think they might have given up on you."

"So you're free now? You can finally leave the car?"

"I think so ..." said the driver. "And you're free to start work again."

"I've been sitting in my office doing nothing for so long," said Vlad. "I'm not sure there's any work left in me."

"You've been reading. And you've been thinking," the driver $\rightarrow$ NATURE.COM said. "I know this isn't Follow Futures on the end for you. I've seen Facebook at: how smart you are."

go.nature.com/mtoodm If anyone had seen
Vlad's potential, the driver had. They had 힙 spent so many afternoons just like this, with Vlad sitting at the window of the car. First it had been the child Vlad discussing his ambitions and his readings, and then the more adult Vlad seriously proposing grand theories to the driver's smiling face.

"Where will you go?" said Vlad.

"I think maybe I'll stay here, with you," the driver said. "At least for a few more years. Don't I owe that to you?"

Wouldn't that be fine? Vlad had sacrificed his whole future for the man. Didn't the driver owe Vlad something?

"No," said Vlad. "I'm not a slave-owner. You should go out into the world."

"Is that what you want?" said the driver. "It wouldn't be slavery, not really... not if I'm choosing it."

A tear fell from Vlad's left eye. "Do you ever wonder what will happen in the future you left behind?" Vlad said. "Why did they need the products of my mind so much? Why were others willing to kill in order to stop me?

"I don't know," said the driver. "Maybe I wasn't even on the right side. But I did my duty. And I would've kept on doing it. You're the one who chose to set me free."

This tear was just the frailest echo of the thousands of tears the child Vlad had wept when he learned how the man was trapped in this car - perhaps forever - by those cruel directives. The student Vlad had formulated a plan. The adult Vlad had carried it out. And the plan had succeeded.

"Get out," Vlad said. "Go. Live."

The car door opened. The driver exited. He was huge. His shoulder was taller than Vlad's head. He was barefoot. Vlad smiled at that. The man hugged Vlad tightly and then walked to the exit of the quad, leaving his car open and empty.

Vlad slammed the car's door. He folded his chair up. He went back to his office and stood in front of his bookshelf. He put a hand on the last book he'd tried to read, and his fingers came away covered in dust.

All his life, Vlad had possessed a destiny. Now he knew that destiny was gone. He smiled. Tomorrow he'd probably feel empty. But today he felt free.

Rahul Kanakia is an international development consultant based in Oakland, California. 